\title{
Nanoparticle Formation Kinetics and Mechanistic Studies Important to Mechanism-Based Particle Size Control: Evidence for Ligand-Based Slowing of the Autocatalytic Surface Growth Step Plus Postulated Mechanisms
}

\author{
Saim Özkar, ${ }^{a}$ Richard G. Finke*b
}

\footnotetext{
${ }^{a}$ Department of Chemistry, Middle East Technical University, 06800 Ankara, Turkey

${ }^{b}$ Department of Chemistry, Colorado State University, Fort Collins, CO 80523 USA
} 
S1. Derivation of Kinetics for the $k_{20 b s}$ vs initial $[A]_{0}=\left[(C O D) I^{I} \cdot P^{\circ} M^{8-}\right]_{0}$ and $\left[\mathrm{POM}^{9-}\right]_{\text {added }}$ concentration Data and Plots from the Bimolecular Nucleation Mechanism

For the bimolecular nucleation mechanism, the differential and integrated forms of the rate law are $\mathrm{S} 1, \mathrm{~S} 2$ and S3, all following prior derivations. ${ }^{1,2}$

$$
\begin{aligned}
& \mathrm{A}+\mathrm{A} \stackrel{k_{1 \mathrm{obs}(\mathrm{bimol})}}{\longrightarrow} 2 \mathrm{~B} \\
& \mathrm{net} 2 \mathrm{~A}+\mathrm{B} \stackrel{k_{2 \mathrm{obs}}}{\longrightarrow} 2 \mathrm{~B} \\
& -\frac{\mathrm{d}[\mathrm{A}]}{\mathrm{dt}}=\frac{\mathrm{d}[\mathrm{B}]}{\mathrm{dt}}=2 k_{1 \mathrm{obs}(\mathrm{bimol})}[\mathrm{A}]_{\mathrm{t}}{ }^{2}+k_{2 \mathrm{obs}}[\mathrm{A}]_{\mathrm{t}}[\mathrm{B}]_{\mathrm{t}} \\
& {[\mathrm{A}]_{\mathrm{t}}=\frac{k_{2 \mathrm{obs}}[\mathrm{A}]_{0}}{2 k_{1 \mathrm{obs}(\mathrm{bimol})}\left\{e^{\left(k_{2 \mathrm{obs}}[\mathrm{A}]_{0} * \mathrm{t}\right)}-1\right\}+k_{2 \mathrm{obs}}}}
\end{aligned}
$$

The proposed more intimate mechanism for the growth step is shown below, (S4) to (S6), along with the associated differential eq S7:

$$
\begin{aligned}
& (\mathrm{COD}) \mathrm{Ir} \cdot \mathrm{POM}^{8-}+2 \mathrm{solv} \stackrel{\mathrm{K}_{\text {Diss }}}{\rightleftharpoons}(\mathrm{COD}) \operatorname{Ir}(\text { solv })_{2}{ }^{+}+\mathrm{POM}^{9-} \\
& {[\mathrm{A}]_{0}-x \quad[\mathrm{solv}]_{0} \quad x \quad\left[\text { POM }^{9-}\right]_{\text {added }}+x} \\
& (\mathrm{COD}) \operatorname{Ir}(\text { solv })_{2}{ }^{+}+\operatorname{Ir}(0)+2.5 \mathrm{H}_{2} \stackrel{k_{2}}{\longrightarrow} 2 \operatorname{Ir}(0)+\mathrm{H}^{+}+\text {cyclooctane }+2 \text { solv } \\
& \begin{array}{lll}
\boldsymbol{x} & \text { B } & 2 \text { B }
\end{array}
\end{aligned}
$$

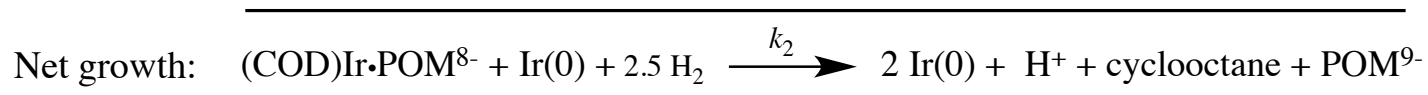

A $\quad 2$ B


For rate-determining autocatalytic growth $k_{2}, \mathrm{~S} 5$, the associated differential equation is $\mathrm{S} 7$ :

$$
\frac{\mathrm{d}[\mathrm{B}]}{\mathrm{dt}}=k_{2}\left[(\mathrm{COD}) \operatorname{Ir}(\operatorname{solv})_{2}^{+}\right][\mathrm{B}]_{t}=k_{2}[x][\mathrm{B}]_{t}
$$

What we need next is an expression for $x$; hence, we can write $\mathrm{K}_{\text {Diss }}$ and $\mathrm{K}_{\text {Diss(apparent) }}=\mathrm{K}_{\text {Diss }}[\operatorname{solv}]^{2}$ :

$$
\begin{aligned}
& \mathrm{K}_{\text {Diss }}=\frac{\left[(\mathrm{COD}) \operatorname{Ir}(\mathrm{solv})_{2}^{+}\right]\left[\mathrm{POM}^{9-}\right]}{\left[(\mathrm{COD}) \mathrm{IrPOM}^{8}\right]\left[\mathrm{solv}^{2}\right.}=\frac{[x]\left(\left[\mathrm{POM}^{9-}\right]_{\text {added }}+x\right)}{\left([\mathrm{A}]_{0}-x\right)\left[\text { solv }^{2}\right.} \\
& \mathrm{K}_{\text {Diss(appt })}=\mathrm{K}_{\text {Diss }}[\mathrm{solv}]^{2}=\frac{[x]\left(\left[\mathrm{POM}^{9-}\right]_{\text {added }}+x\right)}{\left(\left[\mathrm{A}_{0}-x\right)\right.}
\end{aligned}
$$

From eq S9, we can write eq S10 and then from the solution of the quadratic equation, and for the positive root, eq S11

$$
\begin{gathered}
x^{2}+\left(\mathrm{K}_{\text {Diss(appt })}+\left[\mathrm{POM}^{9-}\right]_{\text {added }}\right) x-\mathrm{K}_{\text {Diss(appt })}[\mathrm{A}]_{0}=0 \\
x=\frac{1}{2}\left(-\left(\mathrm{K}_{\text {Diss(appt })}+\left[\mathrm{POM}^{9-}\right]_{\text {added }}\right)+\left(\left(\mathrm{K}_{\text {Diss(appt })}+\left[\mathrm{POM}^{9-}\right]_{\text {added }}\right)^{2}+4 \mathrm{~K}_{\text {Diss(appt })}[\mathrm{A}]_{0}\right)^{1 / 2}\right)
\end{gathered}
$$

Now comparing and equating eqs S2 and S7 yields eq 12 for the growth step:

$$
\frac{\mathrm{d}[\mathrm{B}]}{\mathrm{dt}}=k_{2 \mathrm{obs}}[\mathrm{A}]_{t}[\mathrm{~B}]_{t}=k_{2}[x][\mathrm{B}]_{t}
$$

For the early part of the growth section of the typically sigmoidal curve, and when fitting just first $\leq 1 / 2$ of the sigmoidal curve as we do (so that the cyclohexene hydrogenation catalytic reporter reaction $(\mathrm{CHHR})$ approximations are better satisfied ${ }^{3}$ ), we can take $[\mathrm{A}]_{t} \approx[\mathrm{A}]_{0}$; that is, eq S13a and $\mathrm{S} 13 \mathrm{~b}$ 


$$
\begin{aligned}
& k_{\text {2obs }}[\mathrm{A}]_{0}[\mathrm{~B}]_{t}=k_{2}[x][\mathrm{B}]_{t} \\
& k_{2 \mathrm{obs}}=\frac{k_{2}[x]}{[\mathrm{A}]_{0}}
\end{aligned}
$$

Substituting eq S11 to S13b yields the desired eq S14:

$k_{\text {2obs }}=\frac{k_{2}}{2[\mathrm{~A}]_{0}}\left(-\left(\mathrm{K}_{\text {Diss }(\text { appt })}+\left[\mathrm{POM}^{9-}\right]_{\text {added }}\right)+\left(\left(\mathrm{K}_{\text {Diss }(\text { appt })}+\left[\mathrm{POM}^{9-}\right]_{\text {added }}\right)^{2}+\right.\right.$ $\left.\left.4 \mathrm{~K}_{\text {Diss(appt) }}[\mathrm{A}]_{0}\right)^{1 / 2}\right)$

Eq S14 was then used to fit the experimental $k_{20 b s}$ vs $\left[\mathrm{POM}^{9}\right]_{\text {added }}$ or the initial $[\mathrm{A}]_{0}=[(1,5-$ $\mathrm{COD})\left[\mathrm{r}^{\mathrm{I}} \cdot \mathrm{POM}^{8-}\right]_{0}$ concentration data.

\section{S2. Derivation of Kinetics for the OFWK 4-Step Mechanism (4-Step Ligand Binding Mechanism)}

The proposed mechanism (and $\mathrm{K}+\mathrm{k}$ definitions) are

$$
\begin{gathered}
\mathrm{A} \cdot \mathrm{L} \stackrel{\mathrm{K}_{\mathrm{A} \cdot \mathrm{L}}}{\rightleftharpoons} \mathrm{A}+\mathrm{L} \\
\mathrm{A} \stackrel{k_{1}}{\longrightarrow} \mathrm{B} \\
\mathrm{A}+\mathrm{B} \stackrel{k_{2}}{\longrightarrow} 2 \mathrm{~B} \\
\mathrm{~B}+\mathrm{L} \stackrel{1 / \mathrm{K}_{\mathrm{B} \cdot \mathrm{L}}}{\rightleftharpoons} \mathrm{B} \cdot \mathrm{L}
\end{gathered}
$$

The $\mathrm{K}_{\mathrm{A} \cdot \mathrm{L}}$ and $\mathrm{K}_{\mathrm{B} \cdot \mathrm{L}}$ equilibrium constants are defined in eq (S19) and eq (S20), respectively:

$$
\mathrm{K}_{\mathrm{A} \cdot \mathrm{L}}=\frac{[\mathrm{A}][\mathrm{L}]}{[\mathrm{A} \cdot \mathrm{L}]}
$$




$$
\mathrm{K}_{\mathrm{B} \cdot \mathrm{L}}=\frac{[\mathrm{B} \cdot \mathrm{L}]}{[\mathrm{B}][\mathrm{L}]} ; \quad \frac{1}{\mathrm{~K}_{\mathrm{B} \cdot \mathrm{L}}}=\frac{[\mathrm{B}][\mathrm{L}]}{[\mathrm{B} \cdot \mathrm{L}]}
$$

The mass balance equations are:

$$
\begin{aligned}
& {[\mathrm{A}]_{\mathrm{tot}}=[\mathrm{A}]_{t}+[\mathrm{A} \cdot \mathrm{L}]_{t}} \\
& {[\mathrm{~L}]_{\mathrm{tot}}=[\mathrm{L}]_{t}+[\mathrm{A} \cdot \mathrm{L}]_{t}+[\mathrm{B} \cdot \mathrm{L}]_{t}}
\end{aligned}
$$

For $[\mathrm{L}]_{\text {tot }} \gg[\mathrm{A}]_{\text {tot }}$, this equation simplifies to

$$
\begin{aligned}
& {[\mathrm{L}]_{\mathrm{tot}} \approx[\mathrm{L}]_{t}} \\
& {[\mathrm{~B}]_{\mathrm{tot}} \approx[\mathrm{B}]_{t}+[\mathrm{B} \cdot \mathrm{L}]_{t}}
\end{aligned}
$$

where it is understood that there is no B at $t=0$, but then B grows as the reaction proceeds. From eq $(\mathrm{S} 19)$ and eqs $(\mathrm{S} 21 \mathrm{a})+(\mathrm{S} 21 \mathrm{c})$ :

$$
[\mathrm{A}]_{\mathrm{t}}=\frac{\mathrm{K}_{\mathrm{A} \cdot \mathrm{L}}[\mathrm{A} \cdot \mathrm{L}]_{t}}{[\mathrm{~L}]_{t}}=\frac{\mathrm{K}_{\mathrm{A} \cdot \mathrm{L}}\left([\mathrm{A}]_{\mathrm{tot}}-[\mathrm{A}]_{t}\right)}{[\mathrm{L}]_{\mathrm{tot}}}=\frac{\mathrm{K}_{\mathrm{A} \cdot \mathrm{L}}[\mathrm{A}]_{\mathrm{tot}}-\mathrm{K}_{\mathrm{A} \cdot \mathrm{L}}[\mathrm{A}]_{t}}{[\mathrm{~L}]_{\mathrm{tot}}}
$$

or

$$
[\mathrm{A}]_{t}[\mathrm{~L}]_{\mathrm{tot}}+\mathrm{K}_{\mathrm{A} \cdot \mathrm{L}}[\mathrm{A}]_{t}=\mathrm{K}_{\mathrm{A} \cdot \mathrm{L}}[\mathrm{A}]_{\mathrm{tot}}
$$

or

$$
[\mathrm{A}]_{t}\left(\mathrm{~K}_{\mathrm{A} \cdot \mathrm{L}}+[\mathrm{L}]_{\mathrm{tot}}\right)=\mathrm{K}_{\mathrm{A} \cdot \mathrm{L}}[\mathrm{A}]_{\mathrm{tot}}
$$

hence,

$$
[\mathrm{A}]_{\mathrm{t}}=\frac{\mathrm{K}_{\mathrm{A} \cdot \mathrm{L}}[\mathrm{A}]_{\mathrm{tot}}}{\mathrm{K}_{\mathrm{A} \cdot \mathrm{L}}+[\mathrm{L}]_{\mathrm{tot}}}
$$

Similarly, from eqs (S20), (S21c) and (S21d) we see that

$$
\begin{aligned}
{[\mathrm{B}]_{\mathrm{t}} } & =\frac{[\mathrm{B} \cdot \mathrm{L}]_{t}}{\mathrm{~K}_{\mathrm{B} \cdot \mathrm{L}}[\mathrm{L}]_{\mathrm{tot}}} \\
\text { or } \quad[\mathrm{B}]_{\mathrm{t}} & =\frac{\left([\mathrm{B}]_{\mathrm{tot}}-[\mathrm{B}]_{t}\right)}{\mathrm{K}_{\mathrm{B} \cdot \mathrm{L}}[\mathrm{L}]_{\mathrm{tot}}}
\end{aligned}
$$




$$
\begin{array}{ll}
\text { or } & {[\mathrm{B}]_{t}[\mathrm{~L}]_{\mathrm{tot}} \mathrm{K}_{\mathrm{B} \cdot \mathrm{L}}+[\mathrm{B}]_{t}=[\mathrm{B}]_{\text {tot }}} \\
\text { or } & {[\mathrm{B}]_{t}\left(\mathrm{~K}_{\mathrm{B} \cdot \mathrm{L}}[\mathrm{L}]_{\mathrm{tot}}+1\right)=[\mathrm{B}]_{\text {tot }}} \\
\text { or } & {[\mathrm{B}]_{t}=\frac{[\mathrm{B}]_{\text {tot }}}{\mathrm{K}_{\mathrm{B} \cdot \mathrm{L}}[\mathrm{L}]_{\mathrm{tot}}+1}}
\end{array}
$$

From the proposed 4-step mechanism, and assuming we are always at equilibrium, then the rate determining steps (rds) are eqs (S16) and (S17). Now for the rds of eq (S17) we can write

$$
-\frac{\mathrm{d}[\mathrm{A}]}{\mathrm{dt}}=k_{1}[\mathrm{~A}]_{\mathrm{t}}+k_{2}[\mathrm{~A}]_{\mathrm{t}}[\mathrm{B}]_{\mathrm{t}}
$$

and by substitution of eqs (S22d) and (S23d)

$$
\begin{gathered}
-\frac{\mathrm{d}[\mathrm{A}]}{\mathrm{dt}}=k_{1} \frac{\mathrm{K}_{\mathrm{A} \cdot \mathrm{L}}[\mathrm{A}]_{\text {tot }}}{\mathrm{K}_{\mathrm{A} \cdot \mathrm{L}}+[\mathrm{L}]_{\text {tot }}}+k_{2} \frac{\mathrm{K}_{\mathrm{A} \cdot \mathrm{L}}[\mathrm{A}]_{\text {tot }}}{\mathrm{K}_{\mathrm{A} \cdot \mathrm{L}}+[\mathrm{L}]_{\text {tot }}} \frac{[\mathrm{B}]_{\text {tot }}}{\mathrm{K}_{\mathrm{B} \cdot \mathrm{L}}[\mathrm{L}]_{\text {tot }}+1} \\
-\frac{\mathrm{d}[\mathrm{A}]}{\mathrm{dt}}=k_{1}\left[\frac{\mathrm{K}_{\mathrm{A} \cdot \mathrm{L}}}{\mathrm{K}_{\mathrm{A} \cdot \mathrm{L}}+[\mathrm{L}]_{\mathrm{tot}}}\right][\mathrm{A}]_{\text {tot }}+k_{2}\left[\frac{\mathrm{K}_{\mathrm{A} \cdot \mathrm{L}}}{\mathrm{K}_{\mathrm{A} \cdot \mathrm{L}}+[\mathrm{L}]_{\text {tot }}}\right]\left[\frac{1}{\mathrm{~K}_{\mathrm{B} \cdot \mathrm{L}}[\mathrm{L}]_{\text {tot }}+1}\right][\mathrm{A}]_{\text {tot }}[\mathrm{B}]_{\text {tot }}
\end{gathered}
$$

where it is understood " $[\mathrm{B}]_{\mathrm{tot}}$ " $=[\mathrm{B}]_{\mathrm{tot}, t}$, that is, the rate-determining step of eq $(\mathrm{S} 17)$ makes $[\mathrm{B}]_{t}$, that is then rapidly partitioned by the $\mathrm{K}_{\mathrm{B} \cdot \mathrm{L}}$ equilibrium:

or

$$
-\frac{\mathrm{d}[\mathrm{A}]}{\mathrm{dt}}=k_{1 o b s}[\mathrm{~A}]_{\mathrm{tot}}+k_{2 o b s}[\mathrm{~A}]_{\mathrm{tot}}[\mathrm{B}]_{\mathrm{tot}, t}
$$

where

$$
\begin{aligned}
& k_{1 o b s}=k_{1}\left[\frac{\mathrm{K}_{\mathrm{A} \cdot \mathrm{L}}}{\mathrm{K}_{\mathrm{A} \cdot \mathrm{L}}+[\mathrm{L}]_{\text {tot }}}\right] \\
& k_{2 o b s}=k_{2}\left[\frac{\mathrm{K}_{\mathrm{A} \cdot \mathrm{L}}}{\mathrm{K}_{\mathrm{A} \cdot \mathrm{L}}+[\mathrm{L}]_{\mathrm{tot}}}\right]\left[\frac{1}{\mathrm{~K}_{\mathrm{B} \cdot \mathrm{L}}[\mathrm{L}]_{\mathrm{tot}}+1}\right]
\end{aligned}
$$

Eqs (S25d) and (S25e) can be converted to eqs (S26a) and (S26b) 


$$
\begin{gathered}
k_{1 o b s}=\frac{k_{1} \mathrm{~K}_{\mathrm{A} \cdot \mathrm{L}}}{\mathrm{K}_{\mathrm{A} \cdot \mathrm{L}}+[\mathrm{L}]_{\mathrm{tot}}} \\
k_{2 o b s}=\frac{k_{2} \mathrm{~K}_{\mathrm{A} \cdot \mathrm{L}}}{\mathrm{K}_{\mathrm{B} \cdot \mathrm{L}}[\mathrm{L}]_{\text {tot }}^{2}+\left(\mathrm{K}_{\mathrm{A} \cdot \mathrm{L}} \mathrm{K}_{\mathrm{B} \cdot \mathrm{L}}+1\right)[\mathrm{L}]_{\text {tot }}+\mathrm{K}_{\mathrm{A} \cdot \mathrm{L}}}
\end{gathered}
$$

Eq (S26b) predicts that a plot of $\mathrm{k}_{2 \text { obs }} \mathrm{vs}[\mathrm{L}]_{\text {tot }}$ will look similar to the one in Figure $\mathrm{S} 1$ and be fit by eq $(\mathrm{S} 26 \mathrm{~b})$.

Next, as for the temperature dependence of just $\mathrm{K}_{\mathrm{A} \cdot \mathrm{L}}$ and $\mathrm{K}_{\mathrm{B} \cdot \mathrm{L}}$, we know

or

$$
\Delta G_{\mathrm{A} \cdot \mathrm{L}}=-\mathrm{RT} \ln \left(\mathrm{K}_{\mathrm{A} \cdot \mathrm{L}}\right)
$$

$$
\Delta G_{\mathrm{B} \cdot \mathrm{L}}=-\mathrm{RT} \ln \left(\mathrm{K}_{\mathrm{B} \cdot \mathrm{L}}\right)
$$

or

$$
\mathrm{K}_{\mathrm{B} \cdot \mathrm{L}}=e^{-\Delta G_{\mathrm{B} \cdot \mathrm{L}} / \mathrm{RT}}
$$

If needed eqs (S27) and (S28) can be substituted into eq (S26) for temperature dependent studies.

As for the temperature dependence, substituting eqs (S27b) and (S28b), we obtain

$$
\begin{gathered}
k_{1 o b s}=\frac{k_{1} e^{-\Delta G_{\mathrm{A} \cdot \mathrm{L}} / \mathrm{RT}}}{e^{-\Delta G_{\mathrm{A} \cdot \mathrm{L}} / \mathrm{RT}}+[\mathrm{L}]_{\mathrm{tot}}} \\
k_{2 o b s}=\frac{k_{2} e^{-\Delta G_{\mathrm{A} \cdot \mathrm{L}} / \mathrm{RT}}}{e^{-\Delta G_{\mathrm{B} \cdot \mathrm{L}} / \mathrm{RT}}[\mathrm{L}]_{\mathrm{tot}}^{2}+\left(e^{-\Delta G_{\mathrm{A} \cdot \mathrm{L}} / \mathrm{RT}} e^{-\Delta G_{\mathrm{B} \cdot \mathrm{L}} / \mathrm{RT}}+1\right)[\mathrm{L}]_{\mathrm{tot}}+e^{-\Delta G_{\mathrm{A} \cdot \mathrm{L} / \mathrm{RT}}}}
\end{gathered}
$$

Note additionally, $\Delta G_{i}=\Delta H_{i}-\mathrm{T} \Delta S_{i}$ can then be substituted into eq (S29) as desired. 


\section{S3. The Pseudo-Elementary-Step Reporter-Reaction Method Employed For Monitoring the Kinetics and COPASI Curve-Fitting According to the OFWK 4-Step Mechanism}

As before, ${ }^{3}$ we use the cyclohexene plus $\mathrm{H}_{2}$ pseudoelementary-step reporter reaction method for following the nanoparticle formation kinetics. In the case of the unimolecular nucleation, 2-step mechanism given by eq (S30) (i.e., and consistent with the postulated mechanism steps (S16) and (S17) above), it has previously been shown ${ }^{3,4,5}$ that the loss of $\mathrm{H}_{2}$ (followed using a sensitive, \pm 0.02 psi pressure transducer), or its equivalent cyclohexene loss by the known 1:1 $\mathrm{H}_{2}$ to cyclohexene stoichiometry, obeys eq (S31). The experimental conditions of the reaction are such that the [cyclohexene]/[A] ratio is chosen to be $\sim 1400$ (actually 1375 in all of the experiments herein) when [A] (the $\left[\left(\mathrm{Bu}_{4} \mathrm{~N}\right)_{5} \mathrm{Na}_{3}(1,5-\mathrm{COD}) \mathrm{Ir} \cdot \mathrm{P}_{2} \mathrm{~W}_{15} \mathrm{Nb}_{3} \mathrm{O}_{62}\right]$ precatalyst) is at what we denote as "standard conditions" of $1.2 \mathrm{mM}$. Note that it is a reasonably good, acceptable approximation to treat the nucleation as unimolecular for the purpose of the COPASI curve-fitting, even if it is experimentally known to be second order and nominally / apparently bimolecular, because (as detailed in an earlier publication $\left.^{1}\right) \mathrm{k}_{\text {lobs }}=\mathrm{k}_{1 \text { obs(bimol) }}[\mathrm{A}]_{\mathrm{t}}=\mathrm{k}_{1 \mathrm{obs}(\mathrm{bimol})}[\mathrm{A}]_{0}$ during the induction period where $[\mathrm{A}]_{\mathrm{t}}=[\mathrm{A}]_{0}$ to a high (>99\%) degree of approximation. ${ }^{1}$

$$
\begin{gathered}
\mathrm{A} \stackrel{k_{1 \mathrm{obs}}}{\longrightarrow} \mathrm{B} \\
\mathrm{net} \quad \mathrm{A}+\mathrm{B} \stackrel{k_{\text {2obs }}}{\longrightarrow} 2 \mathrm{~B} \\
-\frac{\mathrm{d}[\text { cyclohexene }]}{\mathrm{dt}}=k_{1 \text { obs(curvefit })}[\text { cyclohexene }]_{\mathrm{t}}+ \\
k_{2 \text { obs (curvefit) }}[\text { cyclohexene }]_{t} *\left([\text { cyclohexen }]_{0}-[\text { cyclohexene }]_{t}\right)
\end{gathered}
$$

where $k_{1 \mathrm{obs}(\text { curvefit })}=k_{1 \mathrm{obs}}$, but $k_{2 \mathrm{obs}(\text { curvefit })}=k_{2 \mathrm{obs}} /\left([\right.$ cyclohexene]/[A] $)$, or $k_{2 \mathrm{obs} \text { (curvefit) }}=k_{2 \mathrm{obs}} / 1400$ for $1.2 \mathrm{mM}$ precatalyst solutions. 


\section{High Resolution Transmission Electron Microscopy Data For Representative $\operatorname{Ir}(0)_{\mathbf{n}}\left(\operatorname{POM}^{9-}\right)_{\mathrm{m}}$ Nanoparticles Prepared in the Present Study}

We have previously published multiple TEM images of POM-stabilized $\operatorname{Ir}(0)_{\mathrm{n}}\left(\mathrm{POM}^{9-}\right)_{\mathrm{m}}$ nanoparticles formed from $\left(\mathrm{Bu}_{4} \mathrm{~N}\right)_{5} \mathrm{Na}_{3}\left[(1,5-\mathrm{COD}) \mathrm{Ir}^{\mathrm{I}} \cdot \mathrm{P}_{2} \mathrm{~W}_{15} \mathrm{Nb}_{3} \mathrm{O}_{62}\right]$ in propylene carbonate at 22.0 $\pm 0.1^{\circ} \mathrm{C}$, with $1.65 \mathrm{M}$ initial cyclohexene concentration, and with and an initial $\mathrm{H}_{2}$ pressure of 40 psig. ${ }^{6,7,8,9,10}$ Figure $\mathrm{S} 1$ displays HR-TEM images, at two different magnifications, of a representative sample harvested after $10 \mathrm{~h}$ and post showing that 1.0 equivalent of cyclooctane had evolved as determined by GC. Particle size measurements were collected from various HR-TEM images and used to construct the histogram given in Figure S3(C). HR-TEM images of another sample are given in Figure S2.

The average diameter of the POM-stabilized $\operatorname{Ir}(0)_{\mathrm{n}}$ nanoparticles is $1.7 \pm 0.3 \mathrm{~nm}$ for both samples. Polyoxometalate anionic ligand can provide enough stabilization for the $\operatorname{Ir}(0)_{\mathrm{n}}$ nanoparticles so that near-monodipserse ${ }^{11} \operatorname{Ir}(0)_{\mathrm{n}}\left(\mathrm{POM}^{9-}\right)_{\mathrm{m}}$ nanoparticles are formed from the reduction of $\left(\mathrm{Bu}_{4} \mathrm{~N}\right)_{5} \mathrm{Na}_{3}\left[(1,5-\mathrm{COD}) \mathrm{Ir}^{\mathrm{I}} \cdot \mathrm{P}_{2} \mathrm{~W}_{15} \mathrm{Nb}_{3} \mathrm{O}_{62}\right]$ precursor.

The TEM images show that well-formed, almost near-monodisperse (i.e., $\pm 15 \%),{ }^{11}$ $1.74 \pm 0.32( \pm 18 \%)$ nanoparticles are formed, nanoparticles therefore of average size of around $\operatorname{Ir}(0) \sim 200$. 

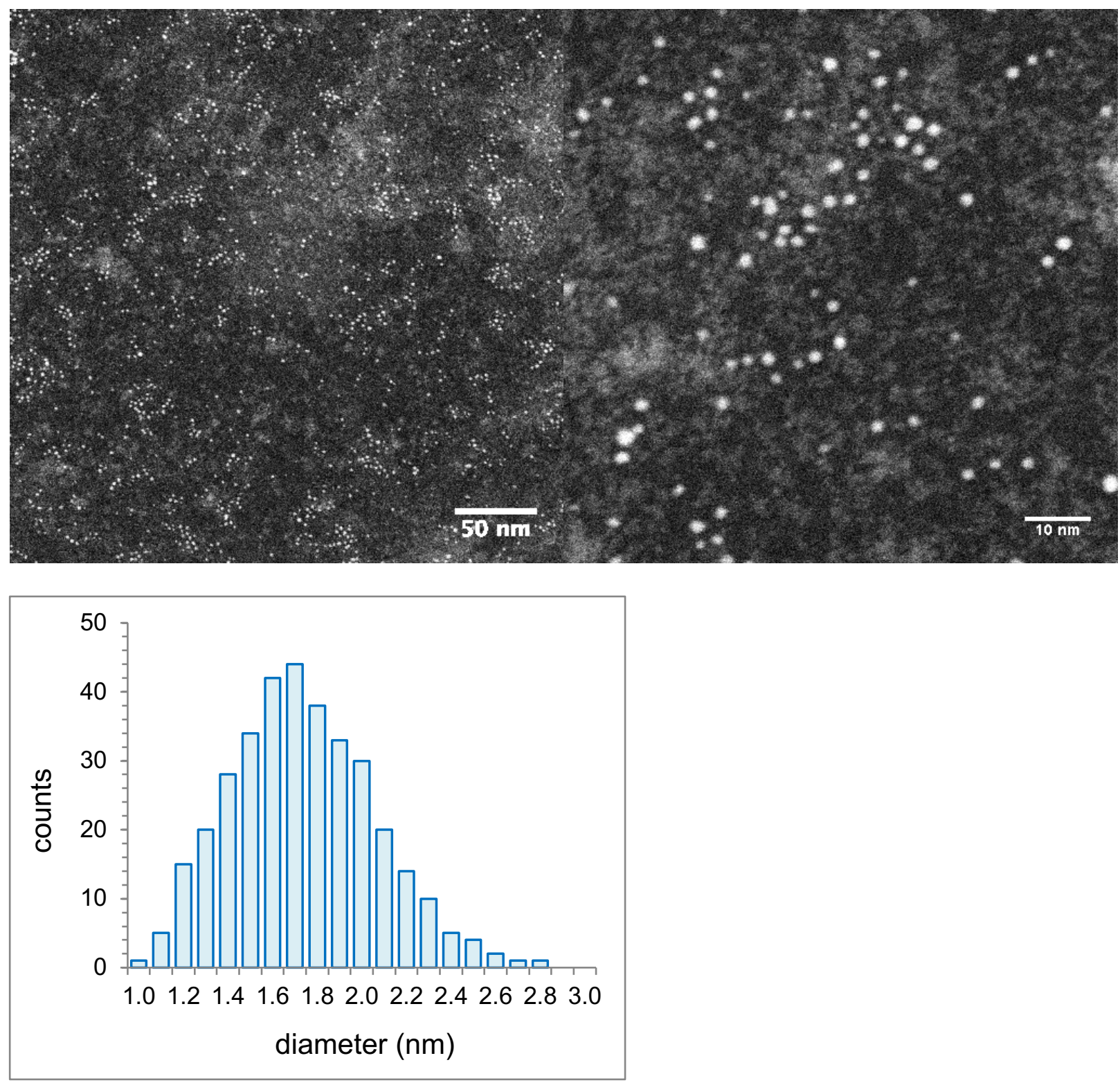

Figure S1. Bright field STEM images (top) and the corresponding particle size histogram (bottom) of $\operatorname{Ir}(0)$ nanoparticles formed during a Standard Conditions nanoparticle formation and concomitant cyclohexene hydrogenation starting with $1.2 \mathrm{mM}\left[\left(\mathrm{Bu}_{4} \mathrm{~N}\right)_{5} \mathrm{Na}_{3}(1,5-\mathrm{COD}) \mathrm{Ir} \cdot \mathrm{P}_{2} \mathrm{~W}_{15} \mathrm{Nb}_{3} \mathrm{O}_{62}\right.$ in propylene carbonate at $22.0 \pm$ $0.1{ }^{\circ} \mathrm{C}, 1.65 \mathrm{M}$ initial cyclohexene concentration, and an initial $\mathrm{H}_{2}$ pressure of $40.5 \mathrm{psig}$. The resultant average diameter is $1.74 \pm 0.32 \mathrm{~nm}$. The histogram was constructed by counting 347 non-touching particles in multiple TEM images. 

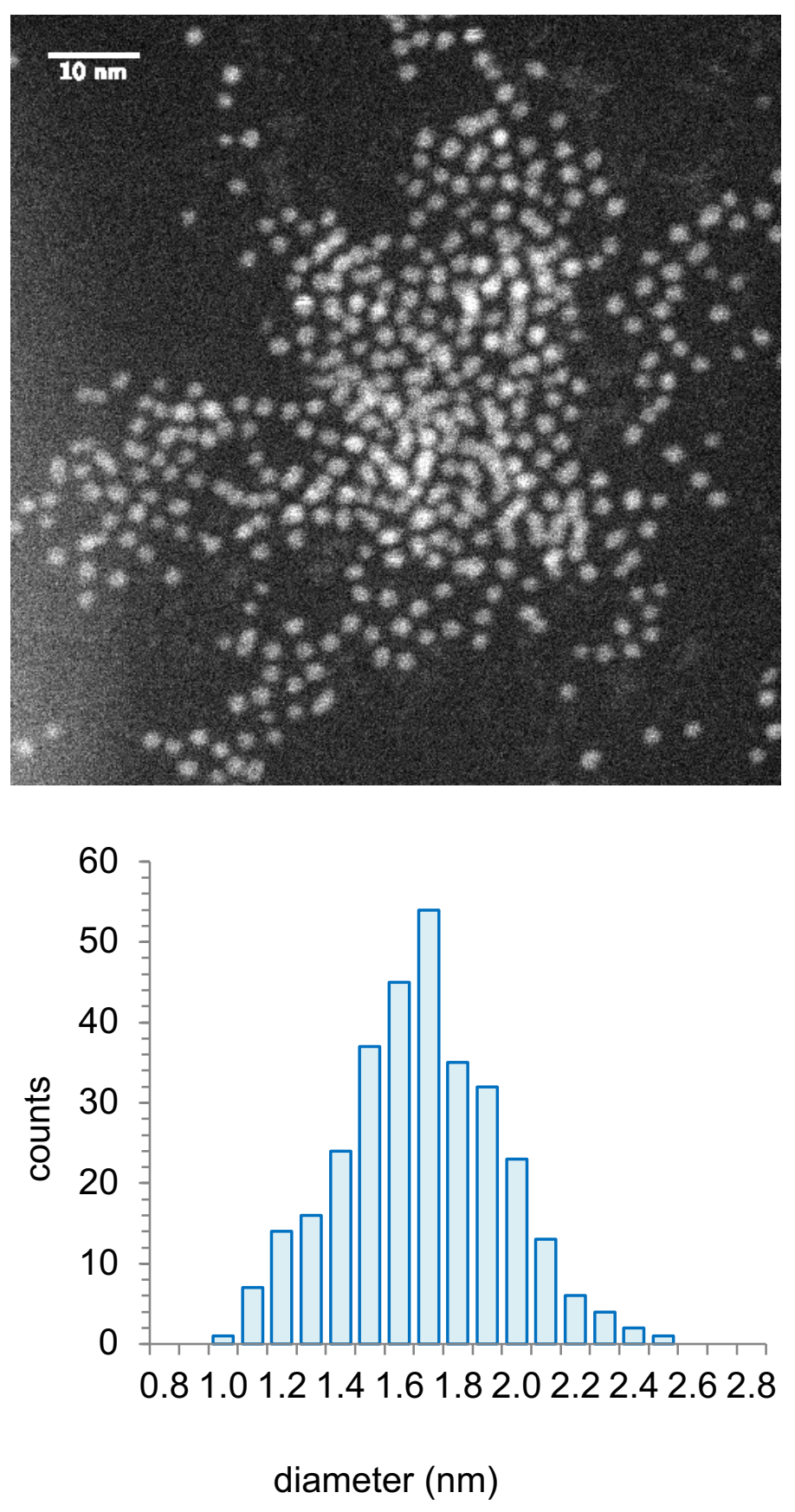

Figure S2. Bright field STEM images (top) and the corresponding particle size histograms (down) of a second sample of $\operatorname{Ir}(0)_{n}$ nanoparticles formed during a Standard Conditions $\operatorname{Ir}(0)_{\mathrm{n}}$ nanoparticle formation reaction and concommitant cyclohexene hydrogenation starting with $1.2 \mathrm{mM}\left[\left(\mathrm{Bu}_{4} \mathrm{~N}\right)_{5} \mathrm{Na}_{3}(1,5-\right.$ $\left.\mathrm{COD}) \mathrm{I} \cdot \mathrm{P}_{2} \mathrm{~W}_{15} \mathrm{Nb}_{3} \mathrm{O}_{62}\right]$ in propylene carbonate at $22.0 \pm 0.1^{\circ} \mathrm{C}$ and an initial $\mathrm{H}_{2}$ pressure of $46.1 \mathrm{psi}(31.4$ psig). The average diameter from this particular reaction is $1.68 \pm 0.2$, and hence the same within experimental error as the sample shown in Figure S1. The histogram was constructed by counting 352 nontouching particles in various TEM images. 
Table S1. Observed rate constant, $k_{2 \text { obs }}$, for the autocatalytic surface growth of $\operatorname{Ir}(0)_{\mathrm{n}}\left(\mathrm{POM}^{9-}\right)_{\mathrm{m}}$ nanoparticles obtained by curve-fitting the CHRR kinetics data to the FW 2-step mechanism. The kinetics data were collected for a Standard Conditions $\operatorname{Ir}(0)_{\mathrm{n}}$ nanoparticle formation and concomitant cyclohexene hydrogenation reporter reaction starting with $\left.[\mathrm{A}]_{\mathrm{o}}=\left[(1,5-\mathrm{COD}) \mathrm{Ir} \cdot \mathrm{P}_{2} \mathrm{~W}_{15} \mathrm{Nb}_{3} \mathrm{O}_{62}\right]^{8-}\right]_{\mathrm{o}}$ precursor plus added polyoxometalate stabilizer $\left[\mathrm{POM}^{9-}\right]_{\text {added }}=\left[\mathrm{P}_{2} \mathrm{~W}_{15} \mathrm{Nb}_{3} \mathrm{O}_{62}{ }^{9-}\right]_{\text {added }}$ in propylene carbonate at $22.0 \pm 0.1{ }^{\circ} \mathrm{C}$, and an initial $\mathrm{H}_{2}$ pressure of $40 \pm 1$ psig, all as described in greater detail elsewhere. ${ }^{1}$

\begin{tabular}{|c|c|c|c|c|}
\hline $\begin{array}{l}\text { Experiment } \\
\text { Number }\end{array}$ & $\begin{array}{c}{\left[\mathrm{Ir}-\mathrm{POM}^{8-}\right]} \\
\text { in } \mathrm{mM}\end{array}$ & $\begin{array}{c}\text { Added }\left[\mathrm{POM}^{9-}\right]_{\text {added }} \\
\text { in } \mathrm{mM}\end{array}$ & $\begin{array}{l}\text { Total }\left[\mathrm{POM}^{9-}\right] \\
\text { in } \mathrm{mM}\end{array}$ & $\begin{array}{c}k_{2 \text { obs }} \\
\text { in } \mathrm{h}^{-1} \mathrm{M}^{-1}\end{array}$ \\
\hline 1 & 0.25 & 0 & 0.25 & 1540 \\
\hline 2 & 0.25 & 0 & 0.25 & 2030 \\
\hline 3 & 0.75 & 0 & 0.75 & 1300 \\
\hline 4 & 0.75 & 0 & 0.75 & 1800 \\
\hline 5 & 0.75 & 0 & 0.75 & 1470 \\
\hline 6 & 1.5 & 0 & 1.5 & 870 \\
\hline 7 & 1.5 & 0 & 1.5 & 880 \\
\hline 8 & 1.5 & 0 & 1.5 & 1840 \\
\hline 9 & 2.61 & 0 & 2.61 & 760 \\
\hline 10 & 3.73 & 0 & 3.73 & 690 \\
\hline 11 & 4.84 & 0 & 4.84 & 550 \\
\hline 12 & 4.84 & 0 & 4.84 & 505 \\
\hline 13 & 6.04 & 0 & 6.04 & 280 \\
\hline 14 & 7.25 & 0 & 7.25 & 305 \\
\hline 15 & 7.25 & 0 & 7.25 & 210 \\
\hline 16 & 8.45 & 0 & 8.45 & 215 \\
\hline 17 & 8.45 & 0 & 8.45 & 157 \\
\hline 18 & 8.45 & 0 & 8.45 & 214 \\
\hline 19 & 1.20 & 0 & 1.20 & 2180 \\
\hline 20 & 1.20 & 0 & 1.20 & 2344 \\
\hline 21 & 1.20 & 0 & 1.20 & 2262 \\
\hline 22 & 1.20 & 0 & 1.20 & 1300 \\
\hline 23 & 1.20 & 0.15 & 1.35 & 1571 \\
\hline 24 & 1.20 & 0.15 & 1.35 & 1245 \\
\hline 25 & 1.20 & 0.15 & 1.35 & 1613 \\
\hline 26 & 1.20 & 0.15 & 1.35 & 1225 \\
\hline 27 & 1.20 & 0.30 & 1.5 & 2414 \\
\hline 28 & 1.20 & 0.30 & 1.5 & 1575 \\
\hline 29 & 1.20 & 0.30 & 1.5 & 958 \\
\hline 30 & 1.20 & 0.60 & 1.8 & 1492 \\
\hline 31 & 1.20 & 0.60 & 1.8 & 1566 \\
\hline 32 & 1.20 & 0.60 & 1.8 & 713 \\
\hline 33 & 1.20 & 0.90 & 2.1 & 1313 \\
\hline 34 & 1.20 & 0.90 & 2.1 & 768 \\
\hline 35 & 1.20 & 0.90 & 2.1 & 720 \\
\hline 36 & 1.20 & 1.2 & 2.4 & 907 \\
\hline 37 & 1.20 & 1.5 & 2.7 & 829 \\
\hline 38 & 1.20 & 1.8 & 3.0 & 761 \\
\hline 39 & 1.20 & 2.1 & 3.3 & 641 \\
\hline
\end{tabular}




\section{Curve-Fitting of Cyclohexene Hydrogenation Reporter Reaction (CHRR) Kinetics Data}

\section{Where No Added POM9- Is Present by the OFWK 4-Step Mechanism Containing the A•L Plus}

\section{B•L Equilibria}

It occurred to us that we should also try to fit the cyclohexene hydrogenation reporter reaction (CHRR) kinetics data back in Figure 1 as a further test of the OFWK 4-Step Mechanism with its $A \cdot L$ and $B \cdot L$ equilibria shown back in Scheme 3 in the main text. Figure $S 3$ shows just such a fit of the experimental CHRR kinetics data using the OFWK 4-step mechanism and COPASI numerical integration software. ${ }^{12}$ The fit is excellent $\left(\mathrm{R}^{2}=0.99026\right)$, perhaps not unexpectedly since the OFWK 4-step mechanism has four additional fitting parameters ${ }^{13}$ over the minimalistic FW 2step mechanism.

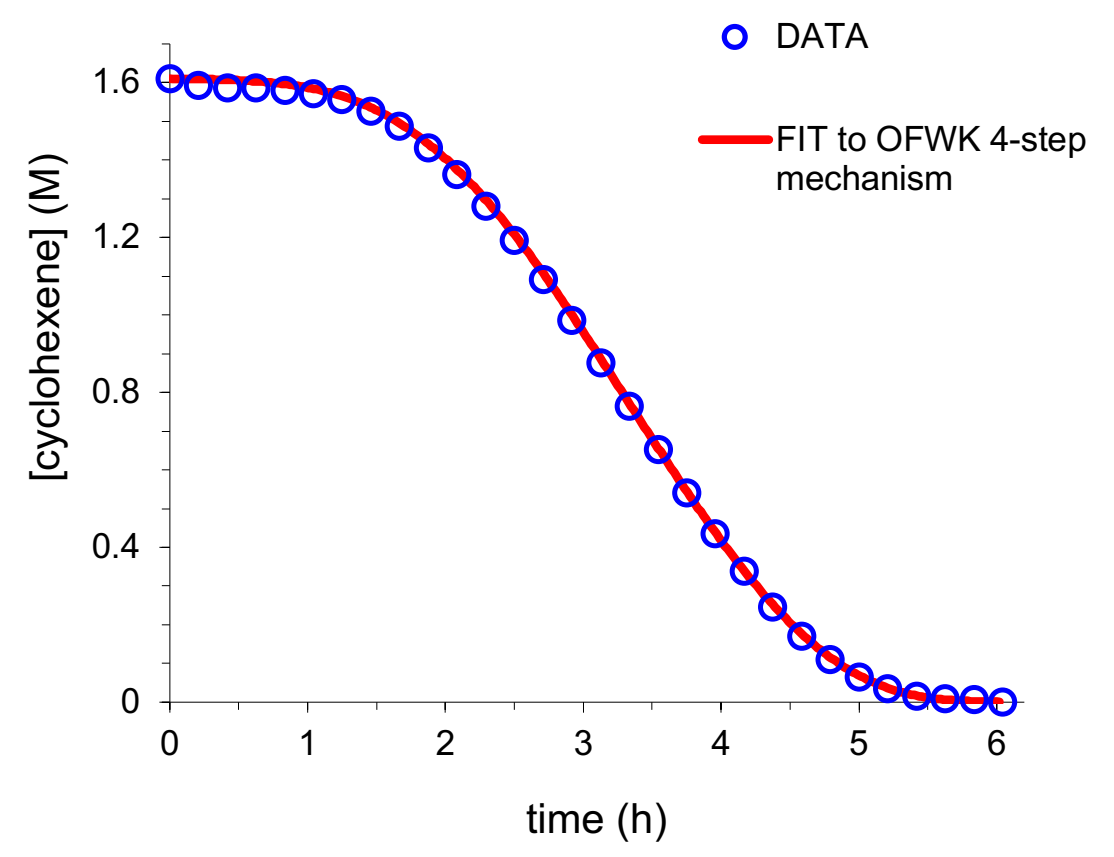

Figure S3. Cyclohexene concentration loss (blue circles) vs time plot for $\operatorname{Ir}(0)_{\mathrm{n}}$ nanoparticle formation and concomitant cyclohexene hydrogenation starting with the Standard Conditions of $1.2 \mathrm{mM}\left[\left(\mathrm{Bu}_{4} \mathrm{~N}\right)_{5} \mathrm{Na}_{3}(1,5-\right.$ $\left.\mathrm{COD}) \mathrm{Ir}^{\mathrm{I}} \cdot \mathrm{P}_{2} \mathrm{~W}_{15} \mathrm{Nb}_{3} \mathrm{O}_{62}\right]$ precursor solution in $2.5 \mathrm{~mL}$ propylene carbonate, $1.65 \mathrm{M}$ initial cyclohexene concentration at $22.0 \pm 0.1{ }^{\circ} \mathrm{C}$, and an initial $\mathrm{H}_{2}$ pressure of $40.6 \mathrm{psig}$ - but with no added POM ${ }^{9-}$. Also shown is the fit (red solid line) of the data to the OFWK 4-step mechanism in Scheme 3. The resultant, COPASI ${ }^{12}$ determined parameters via an unconstrained fitting are: $k_{\mathrm{A} \cdot \mathrm{L}}=34 \pm 17 \mathrm{~h}^{-1}, k_{\mathrm{A} \cdot \mathrm{L}}^{-}=(2.6 \pm 1.2) \times 10^{5} \mathrm{~h}^{-1} \mathrm{M}^{-1}, k_{1}=$ $(8.2 \pm 2.8) \times 10^{-3} \mathrm{~h}^{-1}, k_{2}=(7.7 \pm 0.6) \times 10^{7} \mathrm{~h}^{-1} \mathrm{M}^{-1}, k_{\mathrm{B} \cdot \mathrm{L}}=(5.7 \pm 0.1) \times 10^{4} \mathrm{~h}^{-1}$, and $k_{\mathrm{B} \cdot \mathrm{L}}^{-}=(9.4 \pm 1.2) \times 10^{-2} \mathrm{~h}^{-1}$. The indicated error estimates are from the fit. 
As a check on the curve fitting and equilibrium constants produced in this work, we can check the dissociation equilibrium constant for $\mathrm{A} \cdot \mathrm{L} \rightleftharpoons \mathrm{A}+\mathrm{L}, \mathrm{K}_{\mathrm{A} \cdot \mathrm{L}}=k_{\mathrm{A} \cdot \mathrm{L}} / k_{\mathrm{A} \cdot \mathrm{L}}^{-} \approx 1.3 \times 10^{-6} \mathrm{M}^{-1}$, against the experimental value measured by ${ }^{31} \mathrm{P}$ NMR of ${ }^{1} \mathrm{~K}_{\text {Diss(apparent) }}\left(=\mathrm{K}_{\mathrm{A} \cdot \mathrm{L}}\right.$ (herein) $) \approx 6.4 \times 10^{-5} \mathrm{M}^{-1}$. The agreement is within a factor of $\sim 50$, so rough agreement only. The equilibrium constant for $\mathrm{B} \cdot \mathrm{L} \rightleftharpoons$ $\mathrm{B}+\mathrm{L}, \mathrm{K}_{\mathrm{B} \cdot \mathrm{L}}=k_{\mathrm{B} \cdot \mathrm{L}} / k_{\mathrm{B} \cdot \mathrm{L}}^{-} \approx 1.3 \times 10^{5} \mathrm{M}^{-1}$ from the fit in Figure $\mathrm{S} 3$. This is a $\sim 10^{3}$ order of magnitude larger than the value $\left(\mathrm{K}_{\mathrm{B} \cdot \mathrm{L}}=1.4 \times 10^{2} \mathrm{M}^{-1}\right)$ obtained by fitting the $k_{2 \mathrm{obs}}$ versus $\left[\mathrm{POM}^{9-}\right]_{\text {tot }}$ data to eq (3) in Figure 4 all of the main text. Hence and overall, while the A $\cdot$ L Plus B $\cdot$ L OFWK 4 -step mechanism can fit the $\operatorname{Ir}(0)_{n}\left(\mathrm{POM}^{9-}\right)_{\mathrm{m}}$ nanoparticle formation kinetics data with no added $\mathrm{POM}^{9-}$ present, it remains to (i) be further tested vs other possible mechanisms, and (ii) the ability (or not) of the OFWK 4-step mechanism to obtain reliable equilibrium and rate constants from at least cyclohexene reporter reaction kinetics data remains as another question requiring further testing.

\section{Curve-Fitting of Cyclohexene Hydrogenation Reporter Reaction (CHRR) Kinetics Data With Added POM ${ }^{9-}$ Present by the OFWK 4-Step Mechanism Containing the A $\bullet \mathrm{L}$ Plus B•L Equilibria}

The addition of $\mathrm{POM}^{9-}$ changes the CHRR kinetics, slowing the reaction as expected and leading to a somewhat different shaped kinetics curve, as a comparison of Figures S3 (above) and S4 (blow) reveals. Shown in Figure S4 is a CHRR kinetics curve with 1.8 mM added POM $^{9-}$ along with attempted curve-fits to the FW 2-step and then OFCK 4-step mechanisms. 

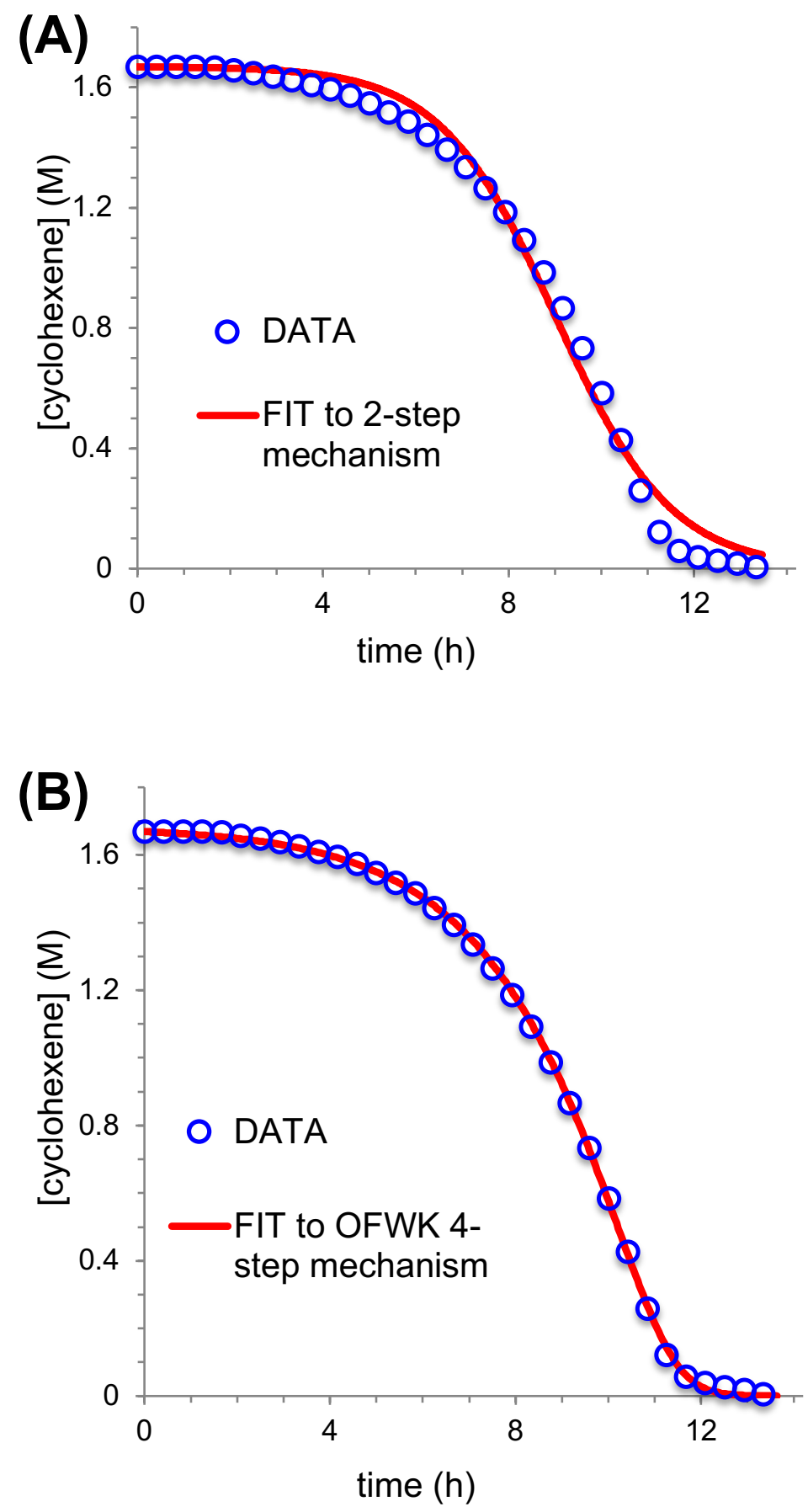

Figure S4. Cyclohexene concentration loss versus time plot for the Standard Conditions $\operatorname{Ir}(0)_{\mathrm{n}}$ nanoparticle formation and concomitant cyclohexene hydrogenation starting with $1.2 \mathrm{mM}\left[\left(\mathrm{Bu}_{4} \mathrm{~N}\right)_{5} \mathrm{Na}_{3}(1,5-\right.$ $\left.\mathrm{COD}) \mathrm{Ir}^{\mathrm{I}} \cdot \mathrm{P}_{2} \mathrm{~W}_{15} \mathrm{Nb}_{3} \mathrm{O}_{62}\right]$ plus $1.8 \mathrm{mM}$ added $\mathrm{POM}^{9-}$ solution and $1.65 \mathrm{M}$ cyclohexene in $2.5 \mathrm{~mL}$ propylene carbonate at $22.0 \pm 0.1^{\circ} \mathrm{C}$ and an initial $\mathrm{H}_{2}$ pressure of $40.7 \mathrm{psig}$. Shown is the fit of data to: (A) the FW 2step mechanism ${ }^{3}$ yielding $k_{\text {lobs }}=(1.7 \pm 0.2) \times 10^{-4} \mathrm{~h}^{-1}$ and $k_{2 \mathrm{obs}}=(6.6 \pm 0.2) \times 10^{2} \mathrm{~h}^{-1} \mathrm{M}^{-1} \mathrm{M}^{-1}, \mathrm{R}^{2}=0.992$; and (B) the OFWK 4-step mechanism (Scheme 3 of the main text) yielding $k_{\mathrm{A} \cdot \mathrm{L}}=14 \pm 64 \mathrm{~h}^{-1}, k_{\mathrm{A} \cdot \mathrm{L}}^{-}=(1.6 \pm$ 6.9 $\times 10^{6} \mathrm{~h}^{-1} \mathrm{M}^{-1}, k_{1}=1.0 \pm 0.9 \mathrm{~h}^{-1}, k_{2}=(5.7 \pm 0.7) \times 10^{8} \mathrm{~h}^{-1} \mathrm{M}^{-1}, k_{\mathrm{B} \cdot \mathrm{L}}=(1.1 \pm 0.6) \times 10^{6} \mathrm{~h}^{-1}$, and $k_{\mathrm{B} \cdot \mathrm{L}}^{-}=0.8 \pm 2.2$ $\mathrm{h}^{-1}, \mathrm{R}^{2}=0.991$. 
Of these two mechanisms, the OFWK 4-step mechanism clearly does the best job of accounting for the CHRR kinetics data when added $\mathrm{POM}^{9-}$ ligand and nanoparticle stabilizer is present, although once again the OFWK mechanism has two additional fitting parameters. However, the resulting fit parameter for the OFWK 4-step mechanism are ill-defined as the bolded error bars above indicate. If one goes ahead anyway and looks at the $\mathrm{K}_{\mathrm{A} \cdot \mathrm{L}}$ and $\mathrm{K}_{\mathrm{B} \cdot \mathrm{L}}$ for the OFWK 4-step mechanism and the curve-fit in Figure S4 Part (B), then $\mathrm{K}_{\mathrm{A} \cdot \mathrm{L}}=k_{\mathrm{A} \cdot \mathrm{L}} / k_{\mathrm{A} \cdot \mathrm{L}}^{-} \approx 8.8 \times 10^{-6} \mathrm{M}^{-1}$ (compared to the ${ }^{31} \mathrm{P}$ NMR obtained value of $\mathrm{K}_{\text {Diss(apparent) }}\left(=\mathrm{K}_{\mathrm{A} \cdot \mathrm{L}}(\right.$ herein $\left.\left.)\right) \approx 6.4 \times 10^{-5} \mathrm{M}^{-1}\right)$ and $\mathrm{K}_{\mathrm{B} \cdot \mathrm{L}}=k_{\mathrm{B} \cdot \mathrm{L}} / k_{\mathrm{B} \cdot \mathrm{L}}^{-} \approx 1.4 \times 10^{6} \mathrm{M}^{-1}$ (compared to $\mathrm{K}_{\mathrm{B} \cdot \mathrm{L}}=1.4 \times 10^{2} \mathrm{M}^{-1}$ obtained by fitting the $k_{2 \mathrm{obs}}$ versus $\left[\mathrm{POM}^{9-}\right]_{\text {tot }}$ data in Figure 4 to

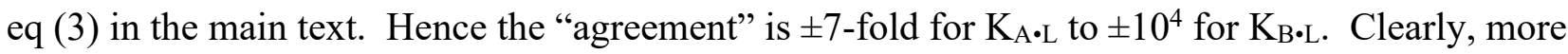
work with additional data sets, and especially by monitoring methods complimentary to and other than the CHRR method, as well as mechanism-enabled population-balance modeling (ME-PBM) ${ }^{14}$ will be needed to identify the best, while still minimum, therefore Ockham's razor obeying, mechanisms when ligands are present.

\section{Curve-Fitting of the Cyclohexene Hydrogenation Reporter Reaction (CHRR) Kinetics Data Without, Then With, Added POM ${ }^{9-}$ Present by a New, 3-Step Mechanism Uncovered via Recent Mechanism-Enabled Population Balance Modeling Efforts ${ }^{14}$}

In recent studies mechanism-enabled population balance studies, the new 3-step mechanism shown in Scheme S1 was uncovered and found to be allow a superior fit to $\operatorname{Ir}(0)_{\mathrm{n}}$ particle-size distributions to at least the mechanisms tested therein. ${ }^{14}$ Hence, it was of interest to try to fit the CHRR without, and then with, added $\mathrm{POM}^{9-}$ to this 3 step mechanism. That attempted fits are shown in Figure S5 and S6.

Scheme S1. The new 3-step mechanism for the nanoparticle formation. ${ }^{14} \mathrm{~A}$ is the nanoparticle precursor, B represents the average smaller, growing nanoparticles, and $\mathrm{C}$ represents the average larger, growing nanoparticles.
$\mathrm{A} \stackrel{k_{1}}{\longrightarrow} \mathrm{B}$
Step (1)
$\mathrm{A}+\mathrm{B} \stackrel{k_{2}}{\longrightarrow} \mathrm{C}$
Step (2)
$\mathrm{A}+\mathrm{C} \stackrel{k_{3}}{\longrightarrow} 1.5 \mathrm{C}$
Step (3) 


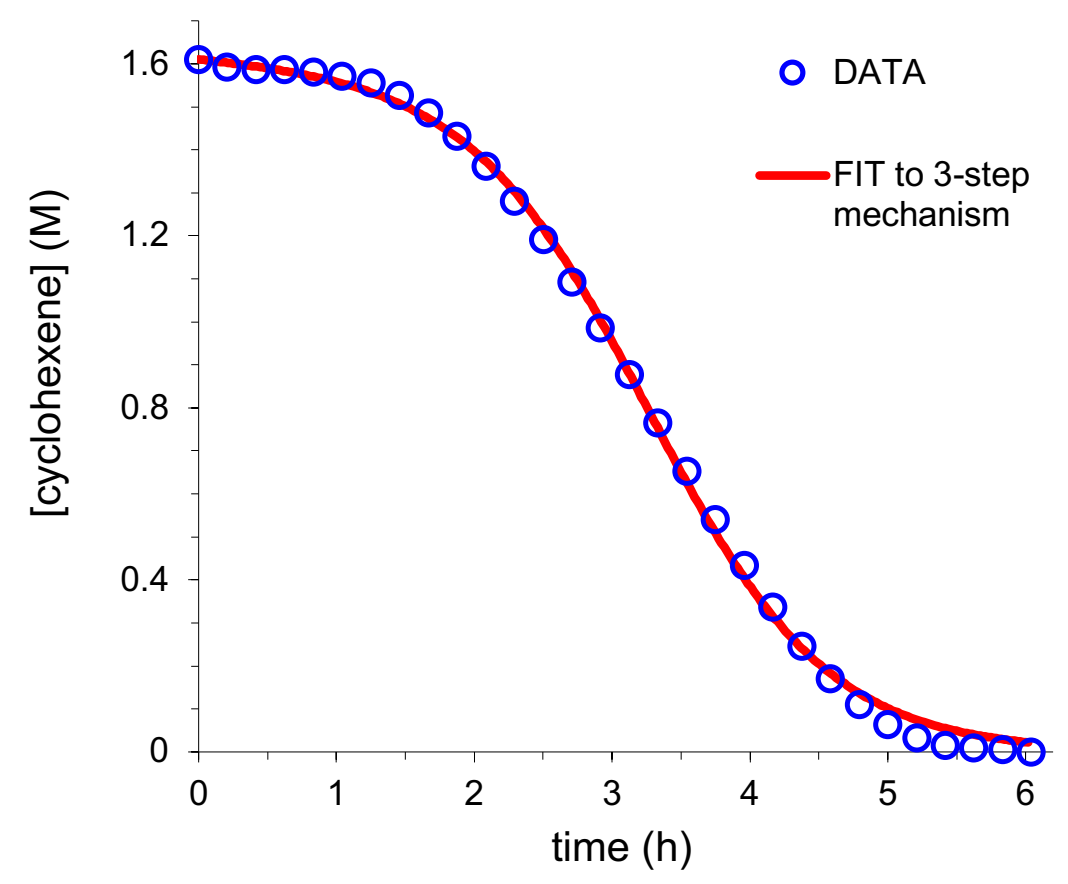

Figure S5. Cyclohexene concentration loss versus time plot for a Standard Conditions $\operatorname{Ir}(0)_{\mathrm{n}}$ nanoparticle formation and concomitant cyclohexene hydrogenation starting with $1.2 \mathrm{mM}\left[\left(\mathrm{Bu}_{4} \mathrm{~N}\right)_{5} \mathrm{Na}_{3}(1,5-\right.$ $\left.\mathrm{COD}) \mathrm{Ir} \cdot \mathrm{P}_{2} \mathrm{~W}_{15} \mathrm{Nb}_{3} \mathrm{O}_{62}\right]$ solution in propylene carbonate, with $1.65 \mathrm{M}$ initial cyclohexene concentration, at $22.0 \pm 0.1{ }^{\circ} \mathrm{C}$, an initial $\mathrm{H}_{2}$ pressure of $40.6 \mathrm{psig}$, but no additional added $P O M^{9-}$. The fit of the data to the new 3-step mechanism ${ }^{14}$ shown above in Scheme 1yields $k_{1}=(2.2 \pm 0.2) \times 10^{-2} \mathrm{~h}^{-1}, k_{2}=(3.7 \pm 0.2) \times 10^{2} \mathrm{~h}^{-1} \mathrm{M}^{-1}$ and $k_{3}=(2.7 \pm 0.2) \times 10^{3} \mathrm{~h}^{-1} \mathrm{M}^{-1}, \mathrm{R}^{2}=0.982$.

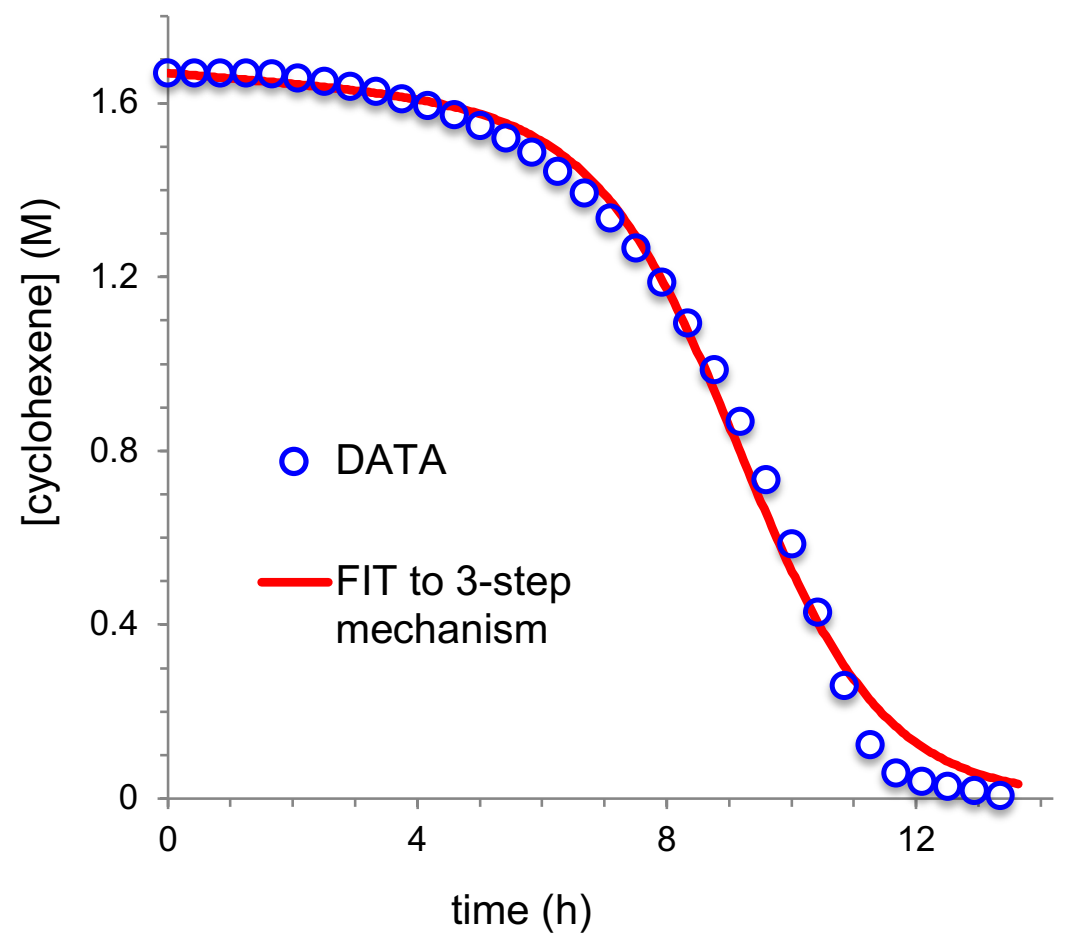


Figure S6. Cyclohexene concentration loss versus time plot for the Standard Conditions $\operatorname{Ir}(0)_{\mathrm{n}}$ nanoparticle formation and concomitant cyclohexene hydrogenation starting with $1.2 \mathrm{mM}$ $\left[\left(\mathrm{Bu}_{4} \mathrm{~N}\right)_{5} \mathrm{Na}_{3}(1,5-\mathrm{COD}) \mathrm{Ir}^{\mathrm{I}} \cdot \mathrm{P}_{2} \mathrm{~W}_{15} \mathrm{Nb}_{3} \mathrm{O}_{62}\right]$ plus $1.8 \mathrm{mM}$ added $P O M^{9-}$ and $1.65 \mathrm{M}$ cyclohexene in propylene carbonate at $22.0 \pm 0.1^{\circ} \mathrm{C}$ and an initial $\mathrm{H}_{2}$ pressure of $40.7 \mathrm{psig}$. Shown is the fit of data to the new 3-step mechanism ${ }^{14}$ to yield $k_{1}=(7.2 \pm 0.6) \times 10^{-3} \mathrm{~h}^{-1}, k_{2}=14 \pm 4 \mathrm{~h}^{-1} \mathrm{M}^{-1}$ and $k_{3}=(1.5 \pm 0.6) \times 10^{3} \mathrm{~h}^{-}$ ${ }^{1} \mathrm{M}^{-1}, \mathrm{R}^{2}=0.955$.

The fits in Figures S5 and S6 teach that while the fit is acceptable when no added POM ${ }^{9-}$ ligand is present, Figure S5, as soon as $1.8 \mathrm{mM} \mathrm{POM}^{9-}$ ligand has been added, the 3-step mechanism provides a less good accounting of the CHRR kinetics data. Additionally, the result of $k_{2}>k_{3}$ does not match (is actually the opposite of) what is found from the mechanism-enabled population-balance modeling (ME-PBM) ${ }^{14}$ of the particle-size distributions, at least when no added POM ${ }^{9-}$ ligand is present. Our hypotheses at this point are supported by the results elsewhere, ${ }^{14}$ namely (i) that the CHRR by itself is unable to unequivocally distinguish the various mechanisms, so (ii) that only when the ME-PBM is used to analyze the PSDs will the underlying minimal mechanism of a given particle formation reaction be more secure. ${ }^{14}$ 


\section{References}

1 Özkar, S.; Finke, R. G. Nanoparticle Nucleation Is Termolecular in Metal and Involves Hydrogen: Evidence for a Kinetically Effective Nucleus of Three $\left\{\operatorname{Ir}_{3} \mathrm{H}_{2 x} \cdot \mathrm{P}_{2} \mathrm{~W}_{15} \mathrm{Nb}_{3} \mathrm{O}_{62}\right\}^{6-}$ in $\operatorname{Ir}(0)_{n}$ Nanoparticle Formation From [(1,5-COD) $\left.\mathrm{Ir}^{\mathrm{I}} \cdot \mathrm{P}_{2} \mathrm{~W}_{15} \mathrm{Nb}_{3} \mathrm{O}_{62}\right]^{8-}$ Plus Dihydrogen, J. Am. Chem. Soc. 2017, 139, 54445457, and references therein.

2 Mondloch, J. E.; Finke, R. G. Kinetic Evidence for Bimolecular Nucleation in Supported-TransitionMetal-Nanoparticle Catalyst Formation in Contact with Solution: The Prototype $\operatorname{Ir}(1,5-\mathrm{COD}) \mathrm{Cl} / \gamma-\mathrm{Al}_{2} \mathrm{O}_{3}$ to $\operatorname{Ir}(0)_{-900} / \gamma-\mathrm{Al}_{2} \mathrm{O}_{3}$ System ACS Catalysis 2012, 2, 298-305.

3 Watzky, M. A.; Finke, R. G. Transition Metal Nanocluster Formation Kinetic and Mechanistic Studies. A New Mechanism When Hydrogen is the Reductant: Slow, Continuous Nucleation and Fast Autocatalytic Surface Growth, J. Am. Chem. Soc., 1997, 119, 10382-10400.Watzky, M. A.; Finke, R. G. J. Am. Chem. Soc. 1997, 119, 10382-10400.

4 Lin, Y.; Finke, R. G. A More General Approach to Distinguishing 'Homogeneous' from 'Heterogeneous' Catalysis: Discovery of Polyoxoanion and $\mathrm{Bu}_{4} \mathrm{~N}^{+}$-Stabilized, Isolable and Redissolvable, High Reactivity Ir $\sim 190-450$ Nanocluster Catalysts”, Inorg. Chem. 1994, 33, 4891-4910.

5 Watzky, M. A.; Finke, R. G. Nanocluster Size-Control and "Magic Number" Investigations. Experimental Tests of the "Living-Metal Polymer" Concept and of Mechanism-Based Size-Control Predictions Leading to the Syntheses of Iridium(0) Nanoclusters Centering About Four Sequential Magic Numbers, Chem. Mater. 1997, 9, 3083-3095.

6 Lin, Y.; Finke, R. G. Novel Polyoxoanion- and $\mathrm{Bu}_{4} \mathrm{~N}^{+}$-Stabilized, Isolable, and Redissolvable, 20-30-.ANG. $\mathrm{Ir}_{300-900}$ Nanoclusters: The Kinetically Controlled Synthesis, Characterization, and Mechanism of Formation of Organic Solvent-Soluble, Reproducible Size, and Reproducible Catalytic Activity Metal Nanoclusters. $J$. Am. Chem. Soc. 1994, 116, 8335-8353.

7 Özkar, S.; Finke, R. G. Nanoparticle Nucleation Is Termolecular in Metal and Involves Hydrogen: Evidence for a Kinetically Effective Nucleus of Three $\left\{\operatorname{Ir}_{3} \mathrm{H}_{2 x} \cdot \mathrm{P}_{2} \mathrm{~W}_{15} \mathrm{Nb}_{3} \mathrm{O}_{62}\right\}^{6-}$ in $\operatorname{Ir}(0)_{n}$ Nanoparticle Formation From [(1,5-COD) $\left.\mathrm{Ir}^{\mathrm{I}} \cdot \mathrm{P}_{2} \mathrm{~W}_{15} \mathrm{Nb}_{3} \mathrm{O}_{62}\right]^{8-}$ Plus Dihydrogen, J. Am. Chem. Soc. 2017, 139, 54445457 , and references therein.

8 Özkar, S.; Finke, R. Dust Effects On Nucleation Kinetics and Nanoparticle Product Size-Distributions: The Illustrative Case Study of a Prototype $\operatorname{Ir}(0)_{\mathrm{n}}$ Transition-Metal Nanoparticle Formation System, Langmuir, 2017, 33, 6550-6562. See also the references in this paper to the history and prior key literature on the effects of dust on particle formation and nucleation kinetics.

9 Özkar, S.; Finke, R. G. Nanocluster Formation and Stabilization Fundamental Studies, Part II: Proton Sponge $^{\mathrm{TM}}$ as an Effective $\mathrm{H}^{+}$Scavenger and Expansion of the Anion Stabilization Ability Series. Langmuir 2002, 18, 7653-7662.

10 Özkar, S.; Finke, R. G. Transition-Metal Nanocluster Stabilization Fundamental Studies: Hydrogen Phosphate as a Simple, Effective, Readily Available, Robust, and Previously Unappreciated Stabilizer for Well-Formed, Isolable, and Redissolvable $\operatorname{Ir}(0)$ and Other Transition-Metal Nanoclusters, Langmuir, 2003, 19, 6247-6260.

11 Aiken' J.D.; Finke, R.G. A Perspective on Nanocluster Catalysis: Polyoxoanion and $\left(n-\mathrm{C}_{4} \mathrm{H}_{9}\right)_{4} \mathrm{~N}^{+}$Stabilized $\operatorname{Ir}(0)_{300}$ Nanocluster 'Soluble Heterogeneous Catalysts' J. Mol. Catal. A 1996, 114, 29-51. 
12 Hoops, S.; Sahle, S.; Gauges, R.; Lee, C.; Pahle, J.; Simus, N.; Singhal, M.; Xu, L.; Mendes, P.; Kummer, U. COPASI - a COmplex PAthway Simulator. Bioinformatics 2006, 22, 3067-3074.

13 Kent, P. D.; Mondloch, J. E.; Finke, R. G. A Four-Step Mechanism for the Formation of SupportedNanoparticle Heterogeneous Catalysts in Contact with Solution: The Conversion of $\operatorname{Ir}(1,5-\mathrm{COD}) \mathrm{Cl} /$ $\mathrm{Al}_{2} \mathrm{O}_{3}$ to $\operatorname{Ir}(0)_{\sim 170} / \quad-\mathrm{Al}_{2} \mathrm{O}_{3}, J$. Am. Chem. Soc. 2014, 136, 1930-1941.

14 Handwerk, D.; Shipman, P. D.; Whitehead C. B., Özkar, S. Finke, R. G. Mechanism-Enabled Population Balance Modeling En Route to Particle Size and Size-Distributions, 2019, submitted. 